\title{
Voices Interwoven: Refrains and Vocal Participation in the Kontakia
}

\begin{abstract}
Refrains were vital to the hymnic genres which emerged in Late Antiquity: the Hebrew piyyut, the Syriac madrasha, and the Greek kontakion. This article studies the complexities of congregational participation by exploring the narrative dynamics of refrains in relation to the hymn-performance in Constantinopolitan churches. The most outstanding and influential refrain composer seems to have been Romanos the Melodist. Through a close reading of his kontakion On the Ten Virgins I (LI) this article shows how thoroughly Romanos enhances the involvement of the assembly, both on a vocal and emotional level. At the same time, the identification of the singer with the narrator in the hymn is carefully blurred. Although many scholars have interpreted kontakia as "verse homilies", the dynamics of the refrains contributes to a destabilization of the roles (teacher-pupils) typical in homilies.
\end{abstract}

Refrains constitute an old poetic devise, older than late antiquity. But in the hymnography of the late ancient period, refrains became an increasingly important feature. The antiphonal singing of a psalm or a Biblical ode in early Christian services was woven together by recurring refrains. ${ }^{1}$ Three important hymn-forms appeared in the Eastern Mediterranean region during the fourth and fifth centuries: the Hebrew piyyut, the Syriac madrasha, and the Greek kontakion; ${ }^{2}$ one of these genres' shared elements is precisely the refrain. Refrains allow the audience, or the group who is gathered around a performer, to take part in the performance vocally; the gathered crowd is not reduced to passive listeners, but gets to sing along. ${ }^{3}$ This may - at least partly - account for the refrains' popularity, especially in ritual settings.

Our printed books often allot liturgical refrains an existence in the gloomy shadows. For certain hymns the refrain is only given once, at the very beginning, and then, as we read, we tend to forget about the whole refrain. Manuscript traditions, too, occasionally omit the refrain. ${ }^{4}$ In this way, the written text gives the completely opposite impression of the performed text. From the performed hymn, the refrain would naturally stand out as the most conspicuous part. After some twenty stanzas of narration and exhortation, individual churchgoers may have paid attention to different aspects of the songs - if they paid attention at all - but what none of them can have missed, is the recurring last line of every stanza.

This observation at least holds true for the kontakion. The entry about refrains (' $\left.\alpha \dot{\alpha} \alpha \kappa \lambda \omega \dot{\omega} \mu \varepsilon v v^{\prime}\right)$ in the Byzantine encyclopedia Suda defines refrains as "That which is being repeated. As [exemplified] in the honorable Romanos the Melodist." In other words, to the authors of Suda, the works of

\footnotetext{
${ }^{1}$ For an overview of Constantinopolitan hymnody and its refrains, see ST.S. FrøYSHOV, Rite of Constantinople. The Canter-

${ }^{2}$ Regarding the three genres, see O. MüNZ-MANOR, Liturgical Poetry in the Late Antique Near East: A Comparative Approach. Journal of Ancient Judaism 1 (2010) 336-361.

${ }^{3}$ J. KodER, Romanos Melodos und sein Publikum: Überlegungen zur Beeinflussung des kirchlichen Auditoriums durch das Kontakion. Anzeiger der philos.-histor. Klasse 134:1 (1999) 64; G. FrAnK, Romanos and the Night Vigil in the Sixth Century, in: Byzantine Christianity, ed. D. Krueger. Minneapolis 2006, 59-78.

${ }^{4}$ The reason for this omission may be that the soloist did not himself sing the refrain, as suggested by E. WeLLESZ, The "Akathistos": A Study in Byzantine Hymnography. DOP 9/10 (1956) 160. On the other hand, the omission or truncation of the refrains may simply arise from the fact that one did not need to reproduce it every time since it was easily learned. In the important Patmos kontakarion (P 212 and 213), in which Romanos's kontakion On the Ten Virgins I is found, the scribe has highlighted the refrains, yet also truncated them. This points both to the significance of the refrain and to a principal of economy in terms of folio space.

${ }^{5}$ English translation by W. HuTTON; trans. and Greek text on Suda On Line <http://www.stoa.org/sol-bin/search.pl>.
} 
Romanos (ca. 490-560) epitomized the very notion of refrains, the repeated words. Hence it is to his kontakia that we must turn if we want to attain a better understanding of the late ancient refrain in the kontakion - and perhaps even in the poetry of the period more generally. ${ }^{6}$

The repeated refrain-line of the kontakia would help the congregation stay focused. The words of the refrain may be appreciated as an important distillate of the hymn's theme. ${ }^{7}$ Historically, there may also be a connection between the refrains and the Byzantine practice of acclamation. ${ }^{8}$ In an article called "Imperial Propaganda in the Kontakia of Romanos the Melode", Johannes Koder states that "In the dialogue between the cantor and the faithful as a whole (or the choir of chanters), the refrain had, with regard to the contents, the function of a confirming response to the latter." Some kontakia, in the same way as earlier hymnody, feature simple refrains like "hallelujah". One may understand these short verses as a means to make a congregation say "aye", "yes", "I believe", "I am with you". There is certainly an element of "propaganda" in the way the refrains must have carved themselves into the minds of the faithful who gathered around the ambo, and who would sing along every time a stanza drew to an end. Romanos the Melodist's most famous Christmas hymn, for instance, has the refrain "a little child, God before the ages." The congregation would sing this twenty-five times on Christmas eve; it is rather improbable that they could have forgotten the phrase the moment they left church. Whether they wanted to or not, these Christians would have had to take Romanos's refrain with them to bed that night, and perhaps wake up with it the next morning. Their whole Christmas celebration may ultimately have been colored by the poet's words. In this sense, the role of the refrain appears simple and didactic: to teach the faithful some brief aphorisms of Christian truth. Moreover, the refrains served to keep the congregation alert as they were physically involved in the singing.

Another idea common among scholars is that the kontakion is "a sermon that was sung", "a sermon in verse", ${ }^{11}$ or "une homélie métrique." 12 The clerical preacher, with his authoritative $I$, simply addressed his audience and taught them in verse. ${ }^{13}$

Yet, this language of simple teaching - or "propaganda" - does not capture the whole picture. Laura Lieber has shown how the Jewish sixth-century poet Yannai is able to transform the Hebrew word 'ōd, "meaning 'yet' or 'again' - a seemingly innocuous word, even dull", into an expression of existential hope for Israel. ${ }^{14}$ Through repetition of this single refrain-word Yannai's piyyut encodes it with a wealthy of meaning. ${ }^{15}$ Koder points to the fact that in several instances the kontakion refrain is made up of a line spoken by one or more of the characters in the "drama", ${ }^{16}$ and

\footnotetext{
${ }^{6}$ For a general introduction to Romanos and his kontakia, see J. GROSDIDIER DE MATONS, Romanos le Mélode et les origines de la poésie religieuse à Byzance. Paris 1977, and the introduction in J. KoDER, Romanos Melodos: Die Hymnen I-II. Stuttgart $2005-2006$.

${ }^{7}$ H. Hunger, Der Refrain in den Kontakia des Romanos Melodos. Vielfalt in der Einheit, in: Lesarten. Festschrift für Athanasios Kambylis, eds. I. Vassis - G.S. Henrich - D.R. Reinsch. Berlin 1998, 53.

${ }^{8}$ Regarding acclamations and ceremonial singing, see e.g. E. Wellesz, A History of Byzantine Music and Hymnography $\left(2^{\text {nd }}\right.$ rev. ed.). Oxford 1961, 109-122.

${ }^{9}$ J. KODER, Imperial Propaganda in the Kontakia of Romanos the Melode. DOP 62 (2008) 288 (italics added). A connection between the salutations in the Akathistos and the political genre of acclamation is proposed in L.M. PeLtOMAA, The Image of the Virgin Mary in the Akathistos Hymn. Leiden 2001, 67.

${ }^{10}$ R.J. SCHORK, Sacred Song from the Byzantine Pulpit: Romanos the Melodist. Gainesville 1995, ix.

${ }^{11}$ P. MAAS \& C.A. TRYPANIS, Sancti Romani Melodi cantica: Cantica genuina. Oxford 1963, xi.

${ }^{12}$ J. Grosdidier de MAtons, Romanos le Mélode: Hymnes I [SC 99]. Paris 1964, 15.

${ }^{13}$ Cf. S.S. Averincev, Poètika rannevizantijskoj literatury. Moscow 1977, 211-212; Chr. Hannick, Zur Metrik des Kon-

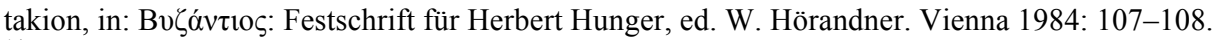

${ }^{14}$ L. LiEBER, The Rhetoric of Participation: Experiential Elements of Early Hebrew Liturgical Poetry. Journal of Religion 90/2 (2010) 127.

${ }^{15}$ The piyyut is a stanzaic genre with which the kontakion shares several features. For a general introduction, consult L.J. WEINBERGER, Jewish Hymnography: A Literary History. London 1998.

${ }^{16}$ KODER, Romanos Melodos und sein Publikum 80-81.
} 
Sarah Gador-Whyte has observed that Romanos's refrains sometimes make the congregation take on different roles. ${ }^{17}$ Yet the picture is even more complex than that. Although refrains are certainly repeated, as Suda indicates, Romanos's refrains did more than simply reiterate themselves. Since the words of the refrain tend to be integrated into the narrative of the kontakion, rather than being a separate chorus, every new repetition, every new narrative setting, potentially renders them with new meaning; they appear in multiple contexts and acquire a complex range of implications. Hence José Grodidier de Matons, the French editor of the Melodist's corpus, admits that Romanos came up with refrains that sometimes created "un effet étrange". ${ }^{18}$ It is these strange effects in the kontakia of Romanos that I am going to explore.

A modern and perhaps more well known piece of writing which employs a refrain is Edgar Allen Poe's poem "The Raven". Its refrain-word "Nevermore" constitutes both an answer and a question at the same time, an incantation and a suppressed cry of lament. For each stanza the expression takes on new meaning. Is "Nevermore" the name of the raven, or the only word it knows - or is it the word of death itself? The raven utters the word, but so does the poetic $I$. It is part of the narrative, while at the same time it stands out as a bad omen that almost departs from the text itself and comments upon it. I will suggest that Romanos used refrains in similar ways; the device serves a more refined purpose than simply enforcing agreement or making people sing " $\mathrm{A} \xi_{1} \circ \varsigma^{\prime}$ " ("Worthy"), as they did for a new Emperor. ${ }^{19}$ Perhaps his refrains had as much in common with that of the famous American poem as with imperial propaganda? I shall explore one particular kontakion, the Melodist's first On the Ten Virgins, and its refrain. ${ }^{20}$ Comparable features do appear in other kontakia as well, but to make my point I need to follow the narrative development of one hymn in some detail. The refrain in this particular kontakion is what Koder calls "Refrain als Anrufung"; its utterance constitutes an imperative cry. ${ }^{21}$ This particular refrain consists of one word only, a word which resembles the above mentioned acclamation quite a bit. The word is "Avor $\xi o v ! "$ ("Open!"). ${ }^{22}$ It is not impossible, of course, that Romanos consciously chose "Avol $\xi_{0}$ ov for its similarity with the acclamation "A $\xi_{10}$, , but while the latter contributes to a verbal closure and conclusion, the former serves to open up the floor of interpretation.

\section{THE TEN VIRGINS}

Romanos's hymn starts from the parable about the ten virgins in the canonical Gospel of Matthew. Since there are some important points in the Gospel text, I shall start by quoting it:

Then the kingdom of heaven will be like this. Ten virgins took their lamps and went to meet the bridegroom. Five of them were foolish, and five were wise. When the foolish took their lamps, they took no oil with them; but the wise took flasks of oil with their lamps. As the bridegroom was delayed, all of them became drowsy and slept. But at midnight there was a shout, "Look!

\footnotetext{
${ }^{17}$ S. GADOR-Whyte, Rhetoric and Ideas in the Kontakia of Romanos the Melodist [PhD thesis]. Melbourne 2011, 13; cf. also Th. AREntzen, The Virgin in Song: Mary and the Poetry of Romanos the Melodist. Philadelphia 2017, 150-153.

${ }^{18}$ Grosdidier de MAtons, Romanos le Mélode 45; for a general introduction to refrains in Romanos, see ibid. 45-47.

${ }^{19}$ De Ceremoniis I 38 (ed. J. J. ReISKe, De Ceremoniis Aulae Byzantinae [CSHB 1]. Bonn 1929, 194).

${ }^{20}$ Romanos LI (ed. J. Grosdidier De MAtons, Hymnes V [SC 283]. Paris 1981, 271-327). The corresponding hymn in the MAAS-TRYPANIS ed. is Canticum XLVIII. The kontakion appears only in the Patmos manuscript. For a general survey of the hymn's literary motifs, see J.H. BARKhuizen, Romanos Melodos, 'On the Ten Virgins' (48 Oxf. = 51 SC). Acta Classica 36 (1993) 39-54.

${ }^{21}$ KodER, Romanos Melodos und sein Publikum 79.

${ }^{22}$ Such a resemblance may seem ironical in the context of my argument, but it should be read, I would suggest, as an example of Romanos's playfulness and irony; irony is, after all, an important and underestimated part of his poetry; see H. HUNGER, Romanos Melodos, Dichter, Prediger, Rhetor - und sein Publikum. JÖB 34 (1984) 20-22.
} 
Here is the bridegroom! Come out to meet him." Then all those virgins got up and trimmed their lamps. The foolish said to the wise, "Give us some of your oil, for our lamps are going out." But the wise replied, "No! there will not be enough for you and for us; you had better go to the dealers and buy some for yourselves." And while they went to buy it, the bridegroom came, and those who were ready went with him into the wedding banquet; and the door was shut. Later the

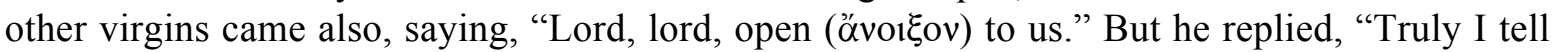
you, I do not know you." Keep awake therefore, for you know neither the day nor the hour (Matt 25.1-13).

This parable is slightly puzzling, for first it seems to suggest that the wise virgins make up examples for the reader, as the heroines of the story. The moral at the end, however, tells the reader to stay awake, which neither the foolish nor the wise ones actually did. What nobody wants, in any case, is to end up outside the door crying and shouting "open up!" like the foolish ones.

Romanos opens his puzzling story with an exhortation to enter the bridal chamber with lamps for Christ:

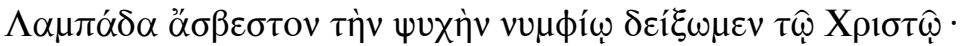

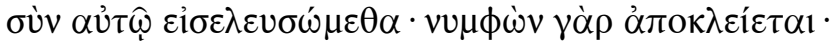

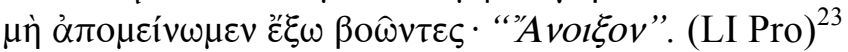

Let us make the soul into an inextinguishable lamp for Christ, the bridegroom;

let us enter with him, for the bridal chamber closes;

let us not wait outside crying "Open!"

Like the Gospel of Matthew, Romanos encourages his congregation to act like the wise virgins and be ready so they may enter with Christ rather than remaining outside. Those who wait outside, we remember, are left crying that Christ must open. As it happens, this is the very word of the hymn's short refrain. After a triad of exhortations, the singer introduces the congregation's line, the very culmination of these verses: Open! Constantinople represents a liturgical realm where doors and entrances played a major part in ritual life; in Robert Taft's words, "Entrances [...] and accessions came to characterize all Byzantine liturgy." 24 The exclamation $\alpha v_{0} \xi_{\mathrm{ov}}$, then, would have had a direct and concrete meaning; to enter means physically to tread into divine space. When the assembly exclaims this command they engage in a speech act; the words accumulate into collective verbal action. ${ }^{25}$

Already in this prelude (the so-called koukoulion or prooimion), however, an irony becomes apparent: The gathered faithful cry out what they want to avoid crying; they take part in the words they wish to shun. In this way they engage from the outset in something more complex and contradictory than a confirming response, a simple amen; Romanos introduces his congregation to a vocal dissonance.

We frequently fail to differentiate between the poetic $I$ and the poet or the singer. When we mean the first person singular of a kontakion, we tend to say "Romanos says this and Romanos says that". Yet the first-person singular of the text does not equal the Romanos of history, however much he may have inscribed himself into the text. This holds true even if we assume that he was

\footnotetext{
${ }^{23}$ The translations are taken from M. CARPENTER, Kontakia of Romanos, Byzantine Melodist, II. Colombia 1973, but I have occasionally moderated them considerably.

${ }^{24}$ R. TAFT, The Byzantine Rite: A Short History. Collegeville 1992, 32.

${ }^{25}$ Cf. LIEBER, The Rhetoric of Participation 123-127; for the theoretical backdrop of speech-act theory, see J.L. AUSTIN, How to Do Things with Words. Cambridge, MA 1962.
} 
the performer of his own kontakia, which he can only have been during his own lifetime. The poetic $I$ of Romanos's corpus amounts to a highly complex phenomenon, in fact, and it often appears as a collective liturgical $I .{ }^{26}$ In this article I make a clear distinction between the poetic $I$, and the author, and the singer(s). Since the kontakia include refrains, there are actually two "performers" or "singers", namely 1) the congregation who sings the refrain and 2) the cantor who sings the rest of the verses. ${ }^{27}$ Hence the poetic $I$ of the hymn points in several directions and should never be identified with the cantor nor with the congregation in any absolute sense. Both of them lend their voices to the poetic $I$, so the song builds an $I$, a dramatic persona, in which everyone is invited to partake.

Already in the first line of On the Ten Virgins, this I addresses his own soul. ${ }^{28}$ Most of the kontakion is actually an inner monologue or the poetic I's dialogue with his own soul. On the other hand, "inner monologue" is not really a fitting phrase since the monologue everts the self so that it turns into an outward and common self, one that the congregation comes to engage in.

In the first oikos, the first regular stanza, the poetic $I$ continues to speak with himself. He attacks his own spiritual distraction and finally urges himself not to be sleepy now when Christ comes, so that he does not end up like the foolish virgin. He says:

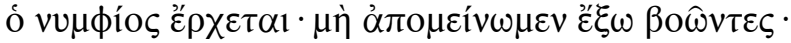

“'Avolgov". (LI 1.11-12)

the bridegroom is coming; we should not remain outside crying:

"Open!"

The poetic $I$ speaks of himself and his soul in plural: we should not be slow, so we wind up having to cry out "Open!" The congregation is asked to serve the interiority of the poetic $I$, and they are invited to take part in his everted monologue. ${ }^{29}$ Their vocal involvement in the interiority of the $I$ renders them on his performative inside, and they come to share in his voice. But the word that they are made to sing leaves them on the outside of Christ's chamber - they cry "Open!" Their voice pronounces the word that the $I$ says he hopes he will not have to utter. The text keeps putting the shunned word in the mouth of the faithful. Their repeated exclamation places them - through their speech act - in the odd position of actually being outside. They are forced to perform verbally their own outsideness. They have to say "Open!" While they wish to be inside, the word that they pronounce inevitably establishes them outside the doors of the chamber. Through their own speech they are placed where they do not want to be.

The $I$ continues to converse with himself and ponder the parable. He tells himself not to be lazy and merciless, for there, in the world to come, the merciless will be judged with mercilessness and the good and wise one will not take pity on the selfish and foolish one. Towards the end of the stanza he exhorts himself - in plural still - to hurry up:

\footnotetext{
${ }^{26}$ On the first person singular in Romanos see D. KRUEGER, Romanos the Melodist and the Christian Self in Early Byzantium, in: Proceedings of the $21^{\text {st }}$ International Congress of Byzantine Studies, London 2006. Vol. I: Plenary Papers, ed. E. Jeffreys. Aldershot 2006, 255-257.

${ }^{27}$ We do not know for sure whether the refrains were actually sung by the congregation or by the choir as a representative of the choir, but scholars generally assume that congregational singing would have been common in Romanos's time. See R. TAFT, Through Their Own Eyes: Liturgy as the Byzantines Saw It. Berkeley 2006, 60-67; Koder, Romanos Melodos und sein Publikum 64; id., Imperial Propaganda 288-290; D. KRUEGER, Liturgical Subjects: Christian Ritual, Biblical Narrative, and the Formation of the Self in Byzantium. Philadelphia 2014, 30. Cf. also H. HunGER, Romanos Melodos: Überlegungen zum Ort und zur Art des Vortrages seiner Hymnen. Mit anschließender kurzer Strukturanalyse eines Kontakions (O 19. SC $35=$ Maria unter dem Kreuz). BZ 92 (1999) 1-9. In any case, the refrain was not sung by the soloist.

${ }^{28}$ Although the virgins are female, the poetic $I$ is male.

${ }^{29}$ Regarding interiority in Romanos, see KRUEGER, Liturgical Subjects.
} 


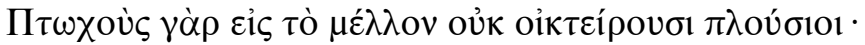

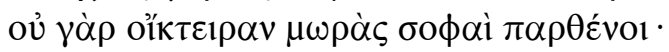

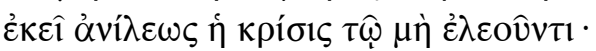

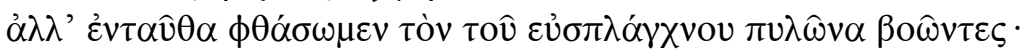

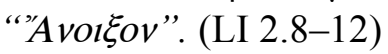

In what is to come, the rich do not pity the poor,

for the wise virgins did not pity the foolish ones.

There the judgment on the merciless is without mercy,

but here we should reach the gate of the Merciful One crying:

"Open!"

The poet appears to have changed his mind. While the former stanza said people should avoid crying "open", this one encourages the same cry. The poetic we should cry "open" at Christ's gate. If we look closely, however, there may be some nuances here which help us make sense of the unexpected shift. The $I$ situates the ten virgins in the realm of the Last Judgment. There, in the eschaton, there is no use in shouting "Open!" But in the present, one may still hope that Christ's door will open up. This complicated negotiation with the parable serves to destabilize its definiteness. The congregant once more exclaims the refrain. Yet he or she must indeed wonder whether this övor $\xi_{0} v$ is now good or bad, useful or not, foolish or wise. For was it not the foolish virgins who cried this? Why ought we to cry with the foolish?

In the ensuing stanzas, the $I$ - much like the seer on Patmos - witnesses how the entire world around him dissolves into earthquakes and wars and thunder and pests. ${ }^{30}$ The end of the world is near. As this extremely scary scene is progressing around the $I$, he realizes that he is not wanted within the salvific doors of the chamber. In his vision, he is left outside, desperately blaming himself and franticly crying: "Open!" Again, the cry belongs to the assembly. The people vocalize and perform the desperation of the poetic $I$, who now appears as one of the foolish virgins. With the foolish virgins and the poetic $I$, the congregation stands outside the doors of Christ, as hell is breaking loose around them.

The poem continues to project frightening scenes for a long time, and there seems to be no end to the miseries:

ö $\tau \varepsilon \pi \hat{\alpha} \sigma \alpha \dot{\eta} \gamma \hat{\eta} \delta \alpha \pi \alpha v \hat{\alpha} \tau \alpha \mathbf{l} \pi v \rho \grave{i}$

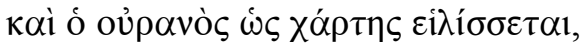

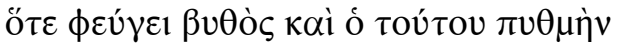

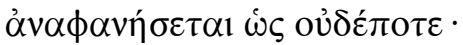

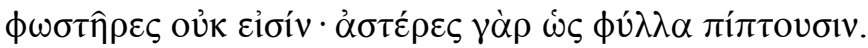

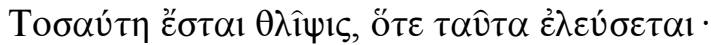

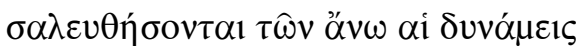

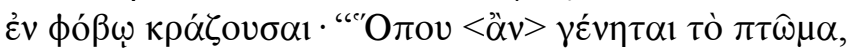

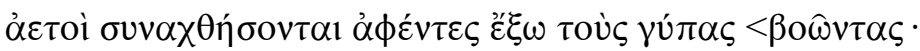

"AvolGov">." (LI 5.3-12)

\footnotetext{
${ }^{30}$ Cf. e.g. Rev. $6.12-14 ; 19.17$ et passim.

${ }^{31}$ The refrain is missing in this stanza. That the refrain is left out in the manuscript is not unique to this stanza or hymn, however.
} 
when the whole earth is consumed by fire

and the sky rolled up like paper,

when the deep sea flees and its very bottom

will be shown forth as never before,

there are no luminaries, for the stars fall like leaves;

so great will be the affliction when these things come to pass,

that the powers above will be made to totter

and scream in fear: "Wherever the carcass is

eagles will be gathered driving out the vultures that are crying:

'Open!','

According to Matthew 24.29, even the powers above will be shaken in the last days. In Romanos's apocalyptic vision it is eventually these powers who speak. The imagery connected to the refrain is slightly shifted, and the ten virgins are eclipsed. The poem moves away from the parable and develops in its own independent ways. For the first time it is not the poetic $I$ who speaks the refrain; it is in fact the vultures - or the vultures according to the powers above, or the powers above according to the poetic $I$. One voice is wrapped into another. The singing people lend their voices to these screaming heavenly powers or the desperate vultures.

The frightening scenario that Romanos drew up must have affected the congregation emotionally. The text ultimately suggests that the congregation identify with hungry vultures; their voice turns into the voice of horrific birds of prey. Eagles will exclude them from both food and a safe refuge. In other words, crying "'Avor $\xi_{0}$ !"” means embodying vultures, the birds of death.

Immediately after the people have exclaimed the vulture-cry, something peculiar happens:

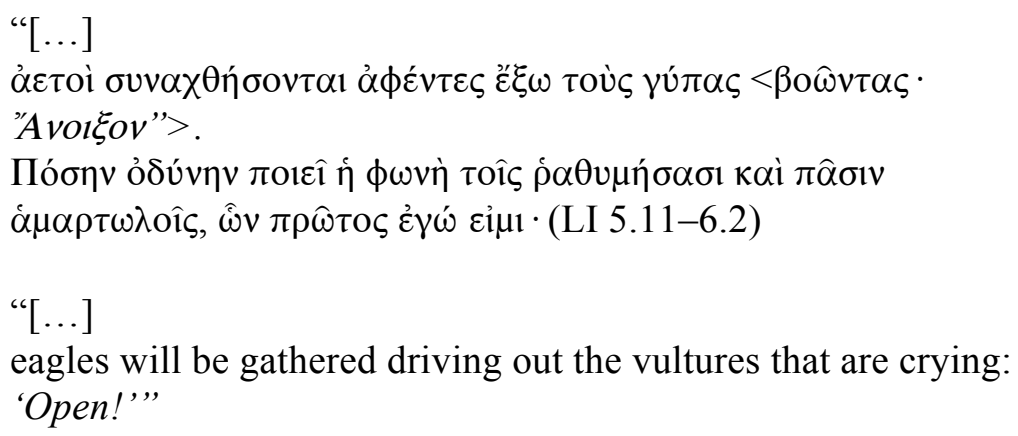

The voice causes woe. This voice or sound enters the hymn quite abruptly. What voice are we talking about here? Does Romanos mean the sound of cataclysm, or the voice of the powers above that scream out in fear, or the voice of the vultures? In any case, the voice of the people still echoes in the background, and the indeterminate $\phi \omega v \eta$ of the next line may find an apt reference in that congregational voice. This is one way to interpret it. The people's voice causes woe and anguish.

Among these overlapping voices and their self-referentiality, it is truly difficult to decide what the congregation actually participates in, and how they are supposed to interpret their own voice. But they are vocally involved in a scary groan, and they contribute to a desperate scream in the extraordinarily chaotic and frightening upheaval.

Just a few lines later, the scene changes. The poetic $I$, who is talking to himself again, says he needs to be good so that he will not be left outside having to cry "Open!": 


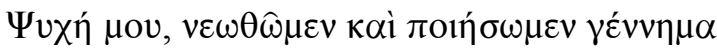

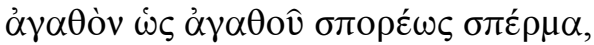

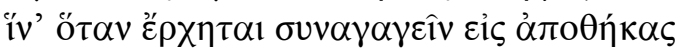

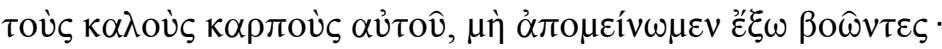

"'Avolgov". (LI 6.8-12)

My soul, let us be renewed and produce a good offspring as a seed of a good sower, so that when he comes to gather into storehouses his good fruits, we shall not remain outside crying:

"Open!"

Naturally, the $I$ wishes to escape the horrific scenes that the listeners just heard about. He wants to repent and enter into Christ. The congregation is back to where it started: Again they are performing that word which the poetic $I$ hopes to avoid.

Then, in the next stanza, it all changes again. The $I$ still talks about his repentance, but now he says that before the great fire consumes him, before the end of the world, he should go with tears and cry "Open!" And similarly in the next stanza he explains that humans will be consumed by the

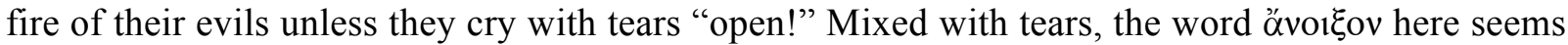
to evolve into an "Open Sesame!" - a magic formula that unlocks the doors. Romanos even relates how Christ punishes the faithless so they learn to cry "open!" (LI 9).

Later (LI 11), the $I$ accuses the big we of lingering too long in the market place. Instead of money, people should care about the divine judgment. In an ironic tone, the $I$ imagines the we to be saying:

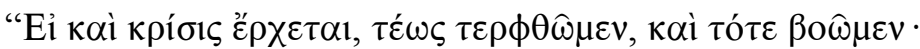

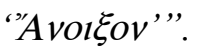

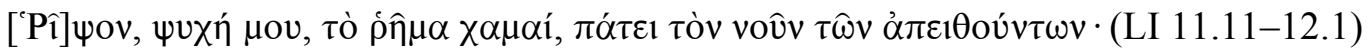

"If indeed judgment comes - let us enjoy ourselves until that time, and then we shall cry:

Open!'”

My soul, cast that phrase to the ground; trample on the meaning of the disobedient;

For the first time in the hymn, the congregation gets to perform their own urban selves, as the text envisions them outside the church walls. Needless to say, this is not how people are supposed to go about the last judgment. Their behavior rather resembles that of the foolish virgins. By singing the refrain here, the congregation is acting out a parody of themselves. The moral flaw belongs to them. By exclaiming "Open!" they are crying out their own inadequacy, and the very word óvor $\xi_{0} v$

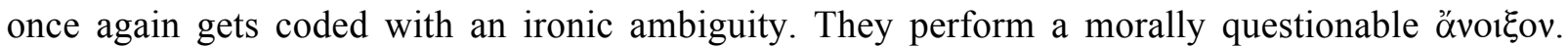
And, as if this was not enough, the poetic $I$ actually says he wants to trample on this very word or phrase. The $I$, in which they participate, trample upon the words of a we in which they participate.

And a similar thing happens a stanza later, when the poetic $I$ again thematizes the word of the refrain, or the phrase it is part of. He imagines Christ to be speaking, and then he himself reacts to Christ's words:

“[...]

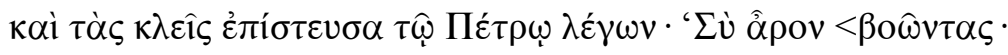

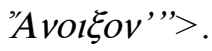

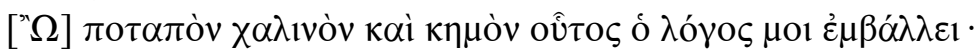




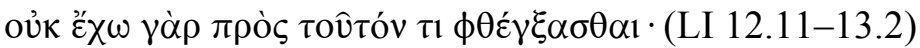

“[...]

I entrusted the keys to Peter, saying, 'Lift up those who cry:

Open!'”,

What a bridle and muzzle this word puts on me,

for I have nothing to say to it;

The moral coding is changing again, for now the $\alpha$ 'vol $\xi_{0} v$ actually does open up the doors to Christ. The word is imagined to come from Christ himself this time. The congregation now performs Christ's word, a word that turns into a plea, which he will answer through his apostle. "Avor $\xi_{0}$ becomes a true prayer, exclaimed by the true friends of Jesus. The poet skillfully weaves the voices of the people into that of the Savior. Once more the "word," to which the I metafictionally refers, may connote the preceding sentence - or the Divine Word who spoke - but it may also simply refer to the word of the refrain, as it resounds through the nave. The word pronounced by the assembly renders the poetic $I$ wordless; he has nothing to say, he says.

The poetic $I$ pretends to be dumbfounded - while in reality, of course, he keeps on talking. And he says to himself:

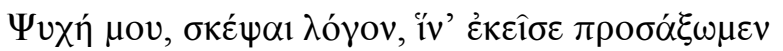

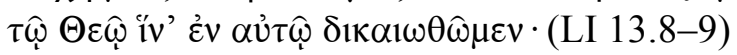

My soul, think of a word, in order that we may go

to God, in order that we may be justified in him;

So he tries to find a word, and eventually he concludes that the way to find justification is to cry "open!" And he starts to inscribe the very word in his own mind by repeating it: ${ }^{32}$

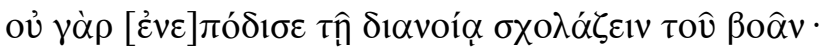

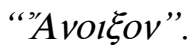

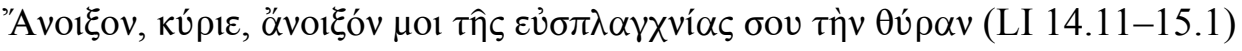

it did not keep [us] from devoting time to the meaning of crying:

"Open!"

Open, Lord, open for me the door of your compassion

The congregation shouts "open!" and the soloist answers like an echo: open! open! The word itself almost turns into an object of meditation. At this point the poetic $I$ (as a dramatic persona) reaches the end of his monologue. He closes his own passionate self-accusation and ends up at the cross. He says to Christ:

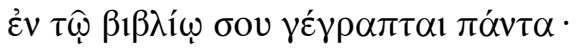

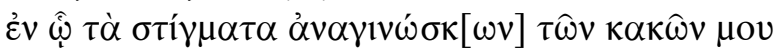

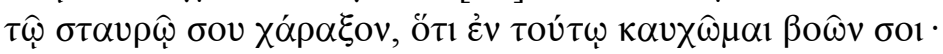

“'AvolGov". (LI 15.9-12)

${ }^{32}$ For stanza 15, see also KRUEGER, Liturgical Subjects 63-64. 
in your book all is written;

as you read in it the marks of my ills

engrave this on your cross that in it I boast crying to you:

"Open!"

The ambiguous references of the pronouns make these lines a bit equivocal, but it is clear that the poetic $I$ makes the crucifixion and his own sins intersect, the cross and his cry. The word for "engrave" creates a half-rhyme with "open". It is as if the refrain itself gets carved into the cross - that cross which makes the Heavenly Kingdom open. So the cry of the congregation eventually comes to converge with the Cross and gets engraved into its wood as it engraves itself into their own minds.

The kontakion ends with a long exhortation to the people. They are encouraged to repent and to cry "Open!" The exclamation "Open!" has turned into a prayer. And "open" is, of course, the very word which the people are already crying. They end up, in other words, urging themselves to do what they are actually doing. The exhortations are fulfilled as they are being performed.

\section{CONCLUSION}

Religious poets of various late ancient traditions developed elaborate uses of the refrain. In this study, Romanos the Melodist has served as a point in case. The refrain may function as a pivot of stability or meditation in a longer poem. Like the "Nevermore" of Edgar Allan Poe's "The Raven", however, the word " $\alpha{ }^{\prime} \xi_{0}$ ov does not cease to evolve. Through the performance of the hymn the congregation exclaims "open" no less than nineteen times, but it constantly changes position throughout the song. To paraphrase Heraclitus, the congregation never enters into the same refrain twice. The three-syllable word takes them through an intricate journey of identification and dissociation - of fear and horror, but also of joy and expectation. First, they exclaim the word which they hope not to exclaim; then, they cry out the same word as a just prayer. The poet makes the subtle distinction between the "open" of today - which does work - and the "open" of the last judgment which does not. Within the frame of the narrative, the word is both effective and ineffective, both immoral and honorable. The people articulate the word of the foolish virgins as they are encouraging themselves to be wise. Longing for inclusion they perform their own exclusion. The word " $\alpha v_{0} \xi_{0} v$ gets associated with the deadly greed of vultures, but also with the transformative powers of the Cross. The congregation plays a vocal part in the multifaceted and multi-voiced poetic $I$ and gets integrated into his self-accusing psychology. They are made to perform and associate with all these different aspects of the övor $\mathrm{ov}_{\text {. }}$

What can we make of this? First of all, by the use of the refrain Romanos is able to decentralize the first person singular of the song. Instead of a preacher that sings to his attentive audience from the ambo of his own $I$, these songs render a self which the singer and the congregation share. Although scripted by the author, they - as performers - eventually all come to teach and exhort themselves.

Secondly, the refrain constitutes more than propaganda, more than the short aphorism which the assembled people may take home with them. The dialogical use of the refrain-line in On the Ten Virgins I rather resembles the function of laughter in connection with comedy: When we watch and laugh, our outbursts express several complex emotions: we may recognize our own silly faults in the character's behavior, laughter may reflect emotional joy, but we may also turn to laughter as the characters take part in revolting or painful deeds; sometimes the absurd and inconceivable makes us laugh. Each time we laugh, the sound of the laughter itself is similar, but its content or meaning differs drastically. And somehow - although it is not necessarily evident why - experiencing the waves of laughter often has a therapeutic effect on the human psychology. The kontakion's dra- 
matic rollercoaster of emotions and scenarios eventually ends up as a comedy with an almost peaceful happy ending. While Romanos first makes his congregation dread the word óvol $\xi_{0}$, and involve them in an ambivalent and uncomfortable way, he eventually turns their dread into prayer, and their "nevermore" into a hope for evermore. 